\title{
Marketing Margin, Price Spread and Marketing Efficiency Analysis on Different Poultry Farms
}

\author{
V. Dinesh and Amod Sharma* \\ Department of Agricultural Economics, SASRD, Nagaland University, \\ Medziphema Campus, Nagaland, India \\ *Corresponding author
}

\section{A B S T R A C T}

\section{Keywords \\ Poultry, Marketing, Pattern, Efficiency, District}

\section{Article Info}

Accepted:

10 May 2019

Available Online:

10 June 2019
A study was conducted to analyze the marketing pattern of poultry layer farms in Namakkal district of Tamil Nadu state, both primary and secondary data were used. The primary data pertained to the year 2018-19 and was elicited from 100 poultry farms and 20 market intermediaries selected and data collected using pre-tested questionnaires. Tabular, financial analysis, on marketing pattern and efficiency technique were employed. The present study revealed that the producer's share in consumer's rupee was 90.00 per cent, the remaining 4.30 per cent accounting for the different costs and 5.70 per cent formed for the wholesaler's margin on channel-I. While on channel-II, the price paid by consumer for eggs sold through this channel was as high as Rs. 4400 per 1000 eggs. The price spread amounted to Rs. 900 per 1000 eggs because both wholesalers and retailers incurred marketing costs and therefore, comparatively the producer's share in the consumer's rupee was reduced to 80.00 per cent, respectively. Hence, the producer's share in consumer's rupee was 92.00 per cent, the remaining 3.40 per cent accounting for the different costs and 4.30 per cent formed for the retailer's margin, respectively.

\section{Introduction}

Presently India exports table eggs and hatching eggs to middle-east to cater to NRI population. India is exporting egg powder, frozen egg yolk and albumen powder to Europe, Japan and other countries. Poultry exports are mostly to Maldives and Oman. Indian poultry meat products have good market in Japan, Malaysia, Indonesia and Singapore. Lack of infrastructure facilities such as poultry disease diagnostic laboratories, feed analytical laboratories, meat testing laboratories, processing, packaging of broilers including developing cold chain for storage and transportation at airports and seaports and speedily handling of cargo etc are major constraints affecting badly the Indian exports. Brand building is yet another area which is not only expensive but also time consuming. The cost of export is also alarming compared to developed countries. The high incidence of customs and excise duties, absence of incentives for exports and 
levy of Income Tax on poultry are other major inhibiting factors hurdling the export growth of India (IPED, 2019).

Presently India exports table eggs and hatching eggs to middle-east to cater to NRI population. India is exporting egg powder, frozen egg yolk and albumen powder to Europe, Japan and other countries. Poultry exports are mostly to Maldives and Oman. Indian poultry meat products have good market in Japan, Malaysia, Indonesia and Singapore. Lack of infrastructure facilities such as poultry disease diagnostic laboratories, feed analytical laboratories, meat testing laboratories, processing, packaging of broilers including developing cold chain for storage and transportation at airports and seaports and speedily handling of cargo etc are major constraints affecting badly the Indian exports. Brand building is yet another area which is not only expensive but also time consuming. The cost of export is also alarming compared to developed countries. The high incidence of customs and excise duties, absence of incentives for exports and levy of Income Tax on poultry are other major inhibiting factors hurdling the export growth of India (Sharma et al., 1999).

Poultry sector in India is valued at about Rs. 80,000 crore (2015-16) broadly divided into two sub-sectors - one with a highly organized commercial sector with about 80.00 per cent of the total market share (say, Rs. 64,000 crore) and the other being unorganized with about 20.00 per cent of the total market share of Rs. 16,000 Crore. The unorganized sector also referred to as backyard poultry plays a key role in supplementary income generation and family nutrition to the poorest of the poor. It is estimated that with a poultry population of 729 million [30.00 per cent layers at around 215 million and 40.00 per cent broilers at around 480 million] small and medium farmers are mostly engaged in contract farming system under larger integrators and there are around 30 million farmers engaged in backyard poultry as per $19^{\text {th }}$ Livestock Census (Anon., 2019).

There are few segments poultry industry, comprising layers, broilers and others. In the egg production layers are kept in cages during their production cycle of 72 weeks. Once their productivity declines, they are sold in the market for consumption. Income from layer farm poultry products includes sale of eggs, cull birds, gunny bags and manure. India is marching ahead towards attaining nutritional security for its people. In this context, poultry eggs, which is highly nutritious and the cheapest source of high quality protein and the poultry meat that is comparatively less expensive than that of red meat (Anon., 2011).

\section{Materials and Methods}

Table 1 reveals that the Namakkal and tiruchengode taluks were purposively selected as these have relatively large number of poultry (layer) farms as compared to other taluks of the district. A list of poultry farms located in each of the selected taluks in Namakkal district was prepared with the help of the staff of the department of animal husbandry. From the list 100 layer farms are selected out of which 25 farms are selected from four blocks or village divisions, the blocks include Namakkal, ernapuram, elachipalayam, mallasamathuram, out of this four blocks Namakkal and ernapuram comes under Namakkal taluk whereas elachipalayam and mallasamuthram comes under tiruchengode taluk. The farms are selected based on multistage random and purposive sampling technique. After collection of data the selected farms are classified in to three groups as small, medium, large based on the number of poultry birds using the mean plus or minus standard deviation formula. The 
birds size less than 11,200 comes under small which included 10 farms, the birds size from 11,200 to 87000 comes under medium farms which included 69 farms and the bird size of above 87000 is taken as large farms which include 21 farms, all the 100 layer farms are selected in the study area are done without looking in to the population. For the purpose of analyzing the marketing aspects of eggs, 10 wholesalers and 10 retail egg centres were selected randomly. Simple statistical tools like averages and percentages were used in to arrive at meaningful results. Similar findings were find out by Aruputharaj and Devi (1979) (Table 2).

\section{Price variation on different marketing channels of poultry farm}

Marketing cost was calculated by estimating the cost incurred in the process of marketing of poultry selling. The cost incurred after product ready for selling till it reaches to the consumers hand generally constitutes the marketing cost. It includes transportation cost, handling cost, storage cost, market fees,

$$
\text { Producer's share in consumer's rupee }=\frac{\text { Producer's price }}{\text { Consumer's price }} x 100
$$

Similarly, the share of total marketing costs and the total marketing margins have also been estimated to analyze the price spread (Sharma et al., 2000).

\section{Price spread}

It was worked out by computing the difference between the sale prices of retailers to consumer and net price received by the producer, as follows (Vengoto and Sharma (2018):

Price spread $=\operatorname{Pr}-\operatorname{Pg}$

Whereas:

$\operatorname{Pr}=$ Price paid by consumer

$\mathrm{Pg}=$ Price received by the growers

\section{Marketing efficiency} marketing efficiency (Sharma et al., 2000).

\section{$\mathrm{ME}=$} price)

Total Marketing cost

\section{Results and Discussion}

weighing charges and labour charges for packing, loading and unloading. The marketing cost at various stages of marketing was calculated and finally the total marketing costs have been computed (adopted from the Choudhary et al., 2017).

The Marketing margin at any stages of marketing has been calculated as follows:

$\mathrm{MM}_{\mathrm{i}}=\mathrm{SP}_{\mathrm{i}}-\left(\mathrm{PP}_{\mathrm{i}}+\mathrm{MC}_{\mathrm{i}}\right)$

Whereas:

$\mathrm{MM}_{\mathrm{i}}=$ Marketing margin of the $\mathrm{i}$-th middleman,

$\mathrm{SP}_{\mathrm{i}}=$ Selling price of the $\mathrm{i}$-th middleman,

$\mathrm{PP}_{\mathrm{i}}=$ Purchasing price of the $\mathrm{i}$-th middleman,

$\mathrm{MC}_{\mathrm{i}}=$ Marketing cost incurred by the i-th middleman

Price spread is the difference between the price paid by the consumer and the price received by the producer. It mainly consists of marketing costs and margins. The price spread analysis was carried out as follows:

The marketing efficiency was calculated by conventional method was used to compute

(Net Price received by the producer - Consumer's

For the present study the price spread in marketing of eggs at Namakkal district was 
covered through three marketing channels, as follows:

\section{Channel-I: $\quad$ Producer-wholesalers- consumers}

Table 3 reveals the analysis of the producer's share of in consumer's price was found to be 90.00 per cent. The costs incurred by wholesalers on egg centre accounted for 0.27 per cent of the consumer's price (Rs. 11 per 1000 eggs), transportation charges formed 2.25 per cent (Rs. 90), labour charges formed Rs. 0.90 per cent (Rs. 36) and the value of breakage of eggs accounted to 0.90 per cent of the consumers price (Rs. 35), respectively. The wholesaler's margin was Rs. 228 per 1000 eggs (5.70 per cent of the consumer's price), hence, the producer's share in consumer's rupee was 90.00 per cent, the remaining 4.30 per cent accounting for the different costs and 5.70 per cent formed for the wholesaler's margin. The price spread and marketing efficiency in this channel was Rs. 400 and 2.30 for 1000 eggs, respectively. Similar findings were in the line of Kent and Sharma (2014).

\section{Channel-II: $\quad$ Producer-Wholesalers- Retailers-Consumers}

Table 4 reveals the marketing costs and margins for this channel for the wholesalers sold the eggs through retailers to the consumer. The wholesalers transported the eggs from the producers to other place and sold them to the retailers in there after keeping a margin of Rs. 306 per 1000 eggs (7.00 per cent of consumer's price). The major costs incurred by the wholesalers were, transportation charges ( 2.40 per cent), labour charges (1.20 per cent) and the value of breakage of eggs ( 0.80 per cent), respectively. While the wholesaler's sale price or retailers purchase price was Rs. 4000 per 1000 eggs (which formed $(80.00$ per cent of the consumer's purchase price). The retailers incurred various costs like transportation ( 1.10 per cent), labour charges $(0.80$ per cent $)$ and the value of breakage of eggs $(0.80$ per cent), respectively. Similar findings were in the line of Sharma (2015).

The retailer's margin was Rs. 272 per 1000 eggs accounting for 6.20 per cent of the consumer's purchase price. The price paid by consumer for eggs sold through this channel was as high as Rs. 4400 per 1000 eggs. The price spread amounted to Rs. 900 per 1000 eggs because both wholesalers and retailers incurred marketing costs and therefore, comparatively the producer's share in the consumer's rupee was reduced to 80 per cent. The marketing efficiency in this channel was 1.80, respectively. Similar findings were in the line of (Sharma et al., 2002).

\section{Channel-III: \\ Producer-Retailers- Consumers}

Table 5 reveals the marketing costs and margins for this channel for the retailers took care of collecting the eggs from the producer unit and, also transporting to their shop. On the other hand, the consumers paid Rs. 3900 per 1000 eggs which formed the consumer's price. The total costs incurred by the retailers consist of the transportation charges, labour charges and the value of breakage of eggs.

The transportation cost accounted for Rs. 134 (3.40 per cent of consumer's price), labour charges formed Rs.36 ( 0.90 per cent) and the value of breakage of eggs was Rs. 35 (0.90 per cent), cost for the egg centre formed Rs.13 (0.30 per cent). Retailer's margin was Rs. 166 per 1000 eggs (4.30 per cent of the consumer's price). Hence, the producer's share in consumer's rupee was 92.00 per cent, the remaining 3.40 per cent accounting for the different costs and 4.30 per cent formed for the retailer's margin. The price spread and 
marketing efficiency in this channel was Rs. Similar findings were in the line of Paney and 300 and 2.20 for 1000 eggs, respectively. Sharma (2018).

Table.1 Taluk wise total poultry population, total number of farms

\begin{tabular}{|c|l|c|c|}
\hline S. No. & \multicolumn{1}{|c|}{ Name of the Taluk's } & Number of farms & Number of birds \\
\hline $\mathbf{1 .}$ & Namakkal & 499 & 24379800 \\
\hline $\mathbf{2 .}$ & Rasipuram & 130 & 6372800 \\
\hline 3. & Paramathivelur & 35 & 1875500 \\
\hline $\mathbf{4 .}$ & Tiruchengode & 168 & 59744500 \\
\hline $\mathbf{5 .}$ & Sendhamangalam & 30 & 2027500 \\
\hline $\mathbf{6 .}$ & Kohill hills & 0 & 0 \\
\hline $\mathbf{7 .}$ & Komarapalayam & 3 & 185000 \\
\hline & Total & 865 & 40815050 \\
\hline
\end{tabular}

(Source: District Animal Husbandry Office, Namakkal, 2017-2018)

Table.2 Number of sample layer farms selected

\begin{tabular}{|c|l|c|c|}
\hline S. No. & \multicolumn{1}{|c|}{ Taluks } & Village divisions & Number of farms \\
\hline \multirow{2}{*}{$\mathbf{1 .}$} & NAMAKKAL & Ernapuram & $25(25.00)$ \\
\cline { 3 - 4 } & & Namakkal & $25(25.00)$ \\
\hline \multirow{2}{*}{ 2. } & \multirow{2}{*}{ TIRUCHENGODE } & Elachipalayam & $25(25.00)$ \\
\cline { 3 - 5 } & & mallasamutharam & $25(25.00)$ \\
\hline & & & $100(100.00)$ \\
\hline
\end{tabular}

(Source: field study)

Table.3 Marketing margin, price spread and marketing efficiency of channel-I

\begin{tabular}{|c|l|c|c|}
\hline $\begin{array}{c}\text { S. } \\
\text { No. }\end{array}$ & \multicolumn{1}{|c|}{ Particulars } & $\begin{array}{c}\text { Amount (Rs/1000 } \\
\text { eggs) }\end{array}$ & $\begin{array}{c}\text { percentage share in } \\
\text { consumers price }\end{array}$ \\
\hline 1. & $\begin{array}{l}\text { Net Price received by Producer / Wholesalers } \\
\text { Purchase Price }\end{array}$ & 3600.00 & 90.00 \\
\hline 2. & Cost incurred by Wholesaler & & \\
\hline a. & Labour Cost & 36.00 & 0.90 \\
\hline b. & Transportation & 90.00 & 2.30 \\
\hline c. & Breakage & 35.00 & 0.90 \\
\hline d. & Cost for Egg Centre & 11.00 & 0.30 \\
\hline e. & Total Marketing Cost incurred by Wholesaler & 172.00 & 4.30 \\
\hline 3. & Wholesaler Margin & 228.00 & 5.70 \\
\hline 4. & Wholesale Sale Price & 4000.00 & 100.00 \\
\hline 5. & Producer Share in Consumers Rupee (\%) & & \\
\hline 6. & Price Spread & & 90.00 \\
\hline 7. & Marketing Efficiency (Ratio) & \multicolumn{2}{|c|}{} \\
\hline
\end{tabular}


Table.4 Marketing margin, price spread and marketing efficiency for channel-II

\begin{tabular}{|c|c|c|c|}
\hline $\begin{array}{l}\text { S. } \\
\text { No. }\end{array}$ & Particulars & $\begin{array}{c}\text { Amount (Rs } \\
\text { per } 1000 \text { egg) }\end{array}$ & $\begin{array}{l}\text { Percentage share in } \\
\text { consumers price }\end{array}$ \\
\hline 1. & $\begin{array}{l}\text { Net Price received by Producer / Wholesalers } \\
\text { Purchase Price }\end{array}$ & 3500.00 & 80.00 \\
\hline 2. & \multicolumn{3}{|c|}{ Cost incurred by Wholesaler } \\
\hline a. & Labour Cost & 54.00 & 1.20 \\
\hline b. & Transportation & 105.00 & 2.40 \\
\hline c. & Breakage & 35.00 & 0.80 \\
\hline d. & Total Marketing Cost incurred by Wholesaler & 194.00 & 4.40 \\
\hline 3. & Wholesaler Margin & 306.00 & 7.00 \\
\hline 4. & Wholesale Sale Price / Retailers Purchase Price & 4000.00 & 91.00 \\
\hline 5. & \multicolumn{3}{|c|}{ Cost incurred by Retailer } \\
\hline a. & Labour Cost & 36.00 & 0.80 \\
\hline b. & Transportation & 47.00 & 1.10 \\
\hline c. & Breakage & 35.00 & 0.80 \\
\hline d. & Cost for Egg Centre & 10.00 & 0.20 \\
\hline e. & Cost incurred by Retailer & 128.00 & 2.90 \\
\hline 6. & Retailers Margin & 272.00 & 6.20 \\
\hline 7. & Retailers Sale Price / Consumers Purchase Price & 4400.00 & 100.00 \\
\hline 8. & Total Marketing Cost & & 322.00 \\
\hline 9. & Total Marketing Margin & & 578.00 \\
\hline 10. & Producer Share in Consumers Rupee (\%) & & 80.00 \\
\hline 11. & Price Spread & & 900.00 \\
\hline 12. & Marketing Efficiency (Ratio) & & 1.80 \\
\hline
\end{tabular}

Table.5 Marketing margin, price spread and marketing efficiency for channel-III

\begin{tabular}{|c|l|c|c|}
\hline S. No. & \multicolumn{1}{|c|}{ Particulars } & $\begin{array}{c}\text { Amount } \\
\text { (Rs /1000 eggs) }\end{array}$ & $\begin{array}{c}\text { Percentage share in } \\
\text { Consumers Price }\end{array}$ \\
\hline $\mathbf{1 .}$ & $\begin{array}{l}\text { Net Price received by Producer / Retailers } \\
\text { Purchase Price }\end{array}$ & 3600.00 & 92.00 \\
\hline $\mathbf{2 .}$ & Cost incurred by Retailer & & \\
\hline a. & Labour Cost & 36.00 & 0.90 \\
\hline b. & Transportation & 50.00 & 1.30 \\
\hline c. & Breakage & 35.00 & 0.90 \\
\hline d. & Cost for Egg Centre & 13.00 & 0.30 \\
\hline e. & Total Marketing Cost incurred by Retailer & 134.00 & 3.40 \\
\hline $\mathbf{3 .}$ & Retailer Margin & 166.00 & 4.30 \\
\hline $\mathbf{4 .}$ & Retailer Sale Price & 3900.00 & 100.00 \\
\hline $\mathbf{5 .}$ & Producer Share in Consumers Rupee (\%) & \multicolumn{2}{|c|}{92.00} \\
\hline $\mathbf{6 .}$ & Price Spread & \multicolumn{2}{|c|}{300.00} \\
\hline $\mathbf{7 .}$ & Marketing Efficiency (Ratio) & \multicolumn{2}{|c|}{} \\
\hline
\end{tabular}


In conclusion, as poultry is one of the important components of animal husbandry activities. It provides additional income and employment opportunities to a large number of people. Poultry production in India has made a huge progress. Poultry enterprise has been one of the important means to alleviate poverty, reduce malnutrition and unemployment among both rural and urban people. In channel-I, Wholesaler's margin was Rs. 228 per 1000 eggs (5.70 per cent of the consumer's price).

The price spread and marketing efficiency in this channel was Rs. 400 and 2.30 for 1000 eggs. In channel-II, wholesaler margin was Rs. 306 per 1000 eggs (7.00 per cent of consumer's price), while the retailer's margin was Rs. 272 per 1000 eggs accounting for 6.20 per cent of the consumer's purchase price. The marketing efficiency was 1.80, while in channel-III, Retailer's margin was Rs. 166 per 1000 eggs (4.30 per cent of the consumer's price). Hence, the price spread and marketing efficiency in this channel was Rs. 300 and 2.2 for 1000 eggs, respectively.

\section{Policy Implications}

Based on the findings of the present investigation following policy implications are drawn:

To improve the marketing efficiency, the producer should sell their produce directly to the wholesalers or having a marketing contract with the retailers.

There is a need to strengthen activities by government in holding the farmers from leaving the layer farming.

\section{References}

Analogous. 2019. National Action Plan for Egg \& Poultry-2022, Department of
Animal Husbandry, Dairying and Fisheries Ministry of Agriculture \& Farmers Welfare Government of India.

Analogous. 2011. Agriculture and Industry Survey. Business Magazine for Agriculture, Indian Poultry Industry. October 20.

Aruputharaj, C. and Devi, Kamala, P. 1979. Economics of Poultry Farming in Tamil Nadu. Madras Agricultural Economics Research Centre, University of Madras. P. 79.

Choudhary, Ramjilal.; Rathore, D.S. and Sharma, Amod. 2017. An Economics Analysis of Production and Marketing of Groundnut in Porbandar District of Gujarat. Economic Affairs. 62(3). September: 547-553.

Kent, Yuntilo. and Sharma, Amod. 2014. Economic Efficiency on different breeds of Poultry birds under Backyard Management System in Dimapur district of Nagaland. Progressive Agriculture. 14(1): 168-177.

Paney, Yani. and Sharma Amod. 2018. Prioritization Strategies for the Resources of Traditional Paddy-CumFish Culture in Lower Subansiri District of Arunachal Pradesh. International Journal of Current Microbiology and Applied Sciences. 7(5). May: 11121124.

Sharma, A. Chauhan, S. Singh, A. K. Sharma, S. K. and Singh, S. P. 2000. Economics Of Milk Production on Different Farm Size Groups. Dairy Guide. XXI(3-4). July to December: 61-66.

Sharma, A. Jha, K. K. and Kulshresthra, R. K. 1999. Human Labour Availability And Utilization Pattern in Co-operative Dairy Sector in Agra District of U.P. Dairy Guide. XX(1-2) January to June: 17-21.

Sharma, A. Sharma, Anamika. and Sharma, S. K. 2002. The scope of improving the existing system of Poultry farming. 
Bioved. 13(1-2). February to August: 147-150.

Sharma, Amod. 2015. Growth and Variability in area, Production and Yield of Cotton Crop. International Journal of Agriculture Innovations \& Research. 4(3). November: 509-511.
Vengoto, Venyo. and Sharma, Amod. 2018. Economic and Constraint of Potato crop in Kohima district of Nagaland. Technoframe. 7(1):75-80. www.tanuvas.ac.in/nea/docs/IPED/pdf. Assessed on $08^{\text {th }}$ May 2019.

\section{How to cite this article:}

Dinesh, V. and Amod Sharma. 2019. Marketing Margin, Price Spread and Marketing Efficiency Analysis on Different Poultry Farms. Int.J.Curr.Microbiol.App.Sci. 8(06): 10391046. doi: https://doi.org/10.20546/ijcmas.2019.806.127 